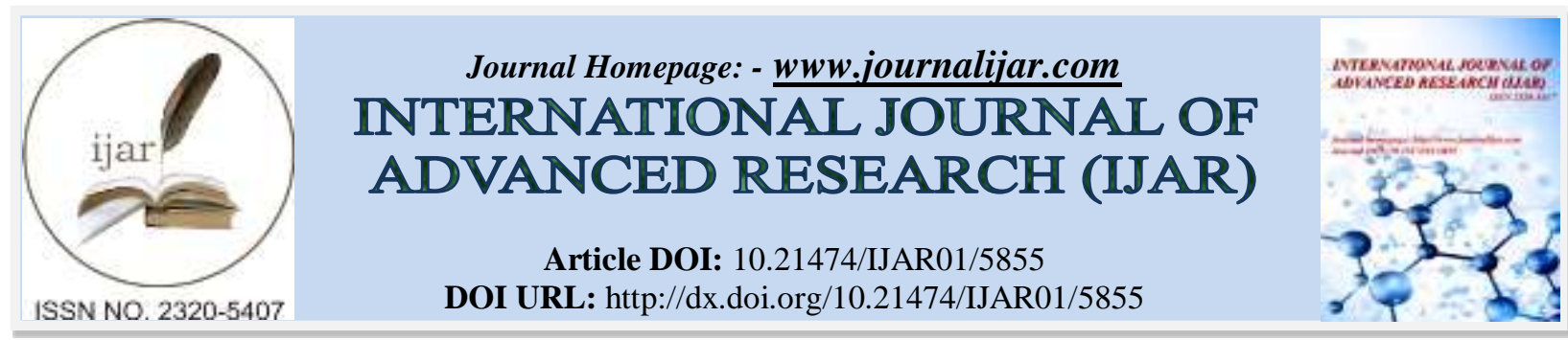

RESEARCH ARTICLE

\title{
PHYSICO CHEMICAL PROPERTIES OF WATER BODIES OF MANUNGPAT, THANGA ISLAND, MANIPUR, INDIA.
}

T. Rebanta Singh ${ }^{1}$, Kh. Rajmani Singh ${ }^{2}$, Ersilia Jajo $^{3}$ and Waribam Suraj Devi ${ }^{4}$.

1. Dept. of Zoology, Jiri College, Jiribam, Manipur.

2. Dept. of Zoology, DM College of Science, Imphal, Manipur.

3. Dept. of Zoology,Pettrigrew College, Ukhrul ,Manipur.

\section{Manuscript Info}

\section{Manuscript History}

Received: 13 September 2017

Final Accepted: 15 October 2017

Published: November 2017

Key words:-

Conducive, KLNP, Manungpat,

Mukapmantha, Physico-chemical,

Thanga island.

\begin{abstract}
This study is aimed to access the drastically changes in water quality of Manungpat of Thanga island which is surrounded by Loktak lake (the largest fresh water lake in North east India) standard methods were used to analyse the variations of different physico-chemical parameters of 4 different sampling sites from February 2016 to February 2017. During the study, the parameters like temperature $\left(15^{\circ} \mathrm{C}-28^{\circ} \mathrm{C}\right)$, Transparency $(50.1 \mathrm{~cm}-120 \mathrm{~cm}), \mathrm{P}^{\mathrm{H}}(7-8.4)$, Total alkalinity $\left(38.5 \mathrm{mgl}^{-1}-99\right.$ $\left.\mathrm{mgl}^{-1}\right)$,Electrical conductivity $\left(59.6 \mu \mathrm{mhoscm}^{-1}-85.6 \mu \mathrm{mhoscm}^{-1}\right), \mathrm{DO}_{2}$ $\left(4.3 \mathrm{mgl}^{-1}-8.5 \mathrm{mgl}^{-1}\right)$, Free $\mathrm{CO}_{2}\left(5.1 \mathrm{mgl}^{-1}-10.7 \mathrm{mgl}^{-1}\right)$, Chloride $\left(1.9 \mathrm{mgl}^{-}\right.$ $\left.{ }^{1}-5.3 \mathrm{mgl}^{-1}\right)$, Magnesium $\left(0.82 \mathrm{mgl}^{-1}-3.24 \mathrm{mgl}^{-1}\right)$, Phosphate $\left(0.011 \mathrm{mgl}^{-1}\right.$ $\left.0.074 \mathrm{mgl}^{-1}\right)$, Potassium $\left(1.11 \mathrm{mgl}^{-1}-4.36 \mathrm{mgl}^{-1}\right)$ were recorded but some were at the permissible level some were very low. At present population explosion and anthropogenic activities had altered its hydrobiology and aggravated so by the excessive growth and proliferation of phumdis (a heterogeneous mass of soil, vegetables and organic matters in different stages of decay).
\end{abstract}

Copy Right, IJAR, 2017,. All rights reserved.

\section{Introduction:-}

Manungpat of Thanga island, a sub- basin of Loktak lake is the southern side of main Thanga island and northern part of Keibul Lamjao National Park, (KLNP - the only floating national park in the world and habitat of endangered species Rucervus eldi eldi). It is under Bishnupur district of Manipur, India and $50 \mathrm{~km}$ from the heart of Imphal city. Being a part of Loktak lake, the climatic condition of the study site is similar to Loktak lake.It is connected to Loktak lake in the north through Thanga chinglak (the hillock, between Thanga Khunusem hill and Thanga main hill) and at the north eastern through Mukap mantha (a place where lies between Mantha hill of Thanga, Bishnupur District and Komlakhong of Mayang Imphal, Thoubal District). Its southern side is extended towards the national park and most people of the area were engaged in fishing since it is the easiest way for their earning. Due to increase in population and its tremendous activities, the quality of water in and around the island is fast deteriorating. The deteriorated condition of water is more or less supported by the excessive growth and proliferation of phumdis (a heterogeneous mass of soil, vegetation and organic matters in different stages of decay).

Corresponding Author:- T. Rebanta Singh.

Address:- Dept. of Zoology, Jiri College, Jiribam, Manipur. 


\section{Materials and Methods:-}

The physico-chemical analysis was done under APHA 1989 at 4(four) different selected sampling sites. Samples were collected in the wee hour of the morning starting from Feb 2016 to February 2017. Some parameter likes Temperature, $\mathrm{p}^{\mathrm{H}}$, Transparency, Conductivity. Dissolve Oxygen \& Free Carbon-dioxide were recorded on the spot. Chloride \& total alkalinity, magnesium, phosphorus, potassium samples were added $2 \mathrm{ml}$ of chloroform per litre in order to analyse at laboratory within 24-72 hrs. The selected sites are namely Moirangthem (site 1), Chinglak( site 2), Mukap-mantha( site 3), Keibul (site 4) respectively.

\section{Result and Discussion:- \\ 3.1 Water temperature:-}

Temperature is the measure of hotness and coldness of any material. Rise in temperature of water causes a number of changes in the growth \&behaviour of aquatic life. Its seasonal and diurnal changes directly influenced the metabolic \& physiological activities. Prasad (1956) reported that temperature is a universal factor \& a slight change in it might affect the hydrobiology of the lake. In the present study the minimum value of temperature $\left(15^{\circ} \mathrm{c}\right)$ was recorded from Site 1 during winter and maximum value $\left(23^{\circ} \mathrm{c}\right)$ from Site2 respectively. The mean water temperature $\left(24.8^{\circ} \mathrm{C}-26.35^{\circ} \mathrm{C}\right)$ was conducive for fish growth (Nath et al., 1994). But this finding may be compared with $\left(12^{\circ} \mathrm{C}-\right.$ $28^{\circ} \mathrm{C}$ ) in Naukuchiyatal lake (Singh, 1981) \& $\left(15^{\circ} \mathrm{C}-31^{\circ} \mathrm{C}\right)$ in nine lakes of Jammu \&Kashmir (Zutshi et al., 1980).

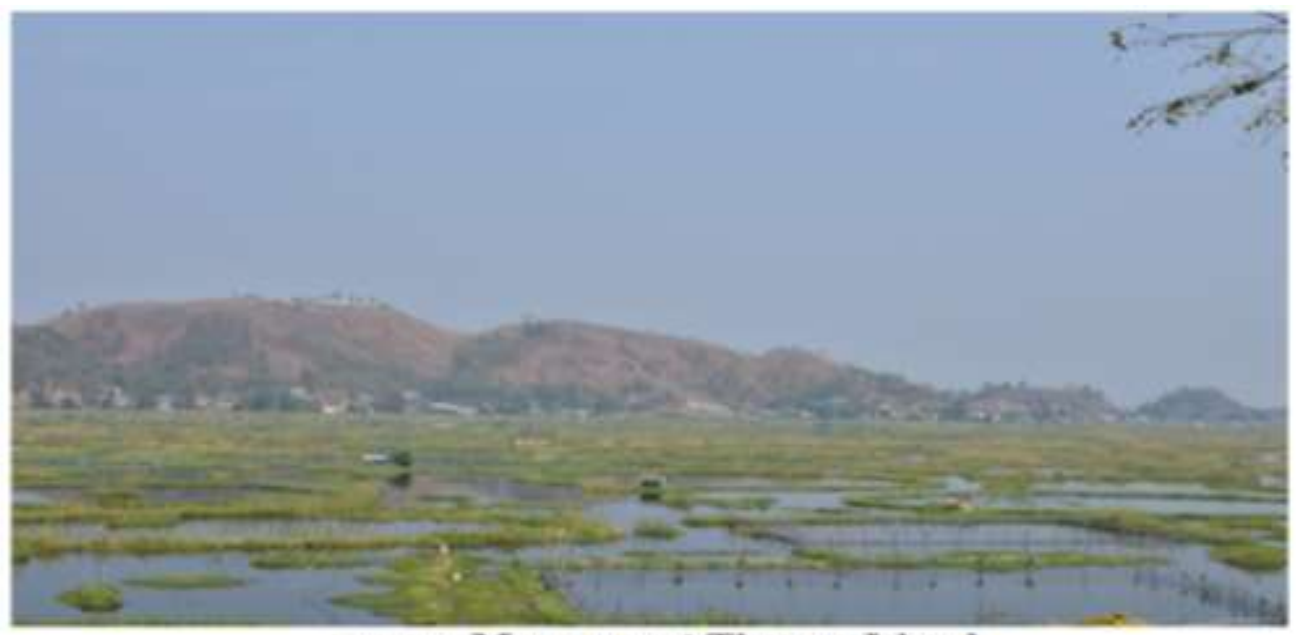

3.2 $\mathrm{P}^{\mathrm{H}}$

Figure 1: Manungpat Thanga Island

$\mathrm{P}^{\mathrm{H}}$ regulates most of biological and chemical reactions in water. The minimum value 7 of $\mathrm{P}^{\mathrm{H}}$ in the lake was recorded from site 1 during June \&maximum value 8.4 from site 4 during November. Generally, mean $\mathrm{P}^{\mathrm{H}}$ range between 7.08.4 was known to be contributed for aquatic life. When the photosynthesis occurs in water there is an increase in oxygen and decrease in carbon dioxide accompanied by increase in $\mathrm{P}^{\mathrm{H}}$ value. Higher value of $\mathrm{p}^{\mathrm{H}}$ in water is probably due to the higher rate of photosynthesis than respiration of living organism as reported by earlier worker Pishak (1996) in Loktak Lake. Decrease in $\mathrm{P}^{\mathrm{H}}$ during the rainy season may be attributed to monsoon rains that cause the formation of carbonic acid $\left(\mathrm{H}_{2} \mathrm{CO}_{3}\right)$ which after dissociation into $\mathrm{H} \& \mathrm{HCO}_{3}$ ions displays acidic character as reported by Khan\& Chowdhury (1994) in Kaptai lake of Bangladesh.

\subsection{Transparency:-}

In the study minimum transparency $(50.1 \mathrm{~cm})$ was recorded at site 1 during monsoon because maximum amount of suspended silts and other particles were carried down into the lake by the feeder streams while maximum transparency $(120 \mathrm{~cm})$ was recorded from site 2 during winter. Nath (2001) reported seasonal fluctuation in transparency with lower values during monsoon and post monsoon months. The high transparency during winter and summer seasons may be due to the absence of silts laden water into the lake from the feeder streams \& rivers as well as gradual settling of split particles \& other suspended particles as reported by Khan \& Chowdhury (1994) for Kaptai lake of Bangladesh . 


\subsection{Total Alkalinity:-}

Total alkalinity ranged between $\left(88 \mathrm{mgl}^{-1}\right.$ and $\left.170 \mathrm{mgl}^{-1}\right)$ which indicates that estuaries might be highly productive (Nath et al 1997, Nath \& De, 1999). Generally, low total alkalinity (less than $40 \mathrm{mgl}^{-1}$ ) indicates poor productivity, while high alkalinity of more than $250 \mathrm{mgl}^{-1}$ in some cases indicates high aquatic pollution. Total alkalinity was minimum during post monsoon (August-October) due to dilution, while maximum content was recorded during winter and summer (Nath \& De, 1999 and Nath, 2001). In the study highest total alkalinity $\left(99.8 \mathrm{mgl}^{-1}\right.$ ) was recorded at site 4 during pre-monsoon and lowest $\left(38.5 \mathrm{mgl}^{-1}\right)$ was recorded at site 2 during monsoon.

\subsection{Electrical Conductivity:-}

Water conductivity is mainly attributed to the dissolved ions liberated from the decompose plant matters (Sarwar \&

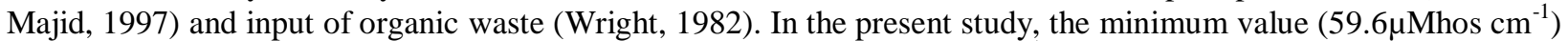

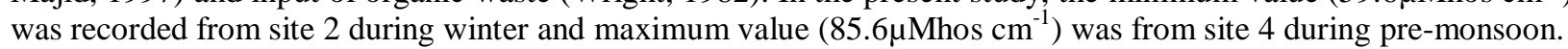

\subsection{Dissolve Oxygen:-}

It was fluctuated in each sites, the minimum value was recorded from site $4\left(4.3 \mathrm{mg}_{-}{ }^{1}\right) \&$ site $3\left(4.5 \mathrm{mgl}^{-1}\right)$ during premonsoon and monsoon of which they are very much closed to the effect of heterogeneous mass of Phumdi and maximum value $\left(8.5 \mathrm{mgl}^{-1}\right)$ was recorded from the open area of site 2 in a sunny day of winter season. Dissolve oxygen content of estuaries ranged between $\left(6.46 \mathrm{mgl}^{-1}-7.28 \mathrm{mgl}^{-1}\right)$ which was conducive for aquatic productivity (Nath \& De, 1999). In general, oxygen is higher during winter season \& pre-monsoon while lower values are found during monsoon \& summer periods. This results may be compared with the finding of Nath (2001) of which highest dissolved oxygen content was recorded during December \& April and lower during June in the Narmada estuary.

\subsection{Free Carbondioxide:-}

Free carbon-dioxide present in water is due to respiration of aquatic biota, decomposition of organic matters infiltration through soil. It is an important parameter of buffer system \& influenced the concentration of carbonate, bicarbonates, $\mathrm{P}^{\mathrm{H}}, \&$ total hardness in water. The values of free carbon-dioxide were recorded as minimum $\left(5.1 \mathrm{mgl}^{-1}\right)$ from the study site 1 during pre-monsoon while maximum $\left(10.7 \mathrm{mgl}^{-1}\right)$ from site 4 during monsoon. More free carbon-dioxide content in aquatic ecosystem might be an indicator of pollution. Higher level of it in monsoon months may be attributed to its influx through rain water in the form of carbonic acid. This is in conformity with the observations of Chakrabarty et al (1959), Methew (1978) \& Mansorri et al (1995). Lower level during summer months might be due to high photosynthetic activity utilizing free carbon-dioxide which is an agreement with the work of Yousuf et al (1986).

\subsection{Chloride:-}

Chloride occurs naturally in all types of water bodies. In natural fresh water, however its concentration remains quite low. The highest chloride value $\left(5.3 \mathrm{mgl}^{-1}\right)$ in the study was recorded from site 1 during summer and lowest $\left(1.9 \mathrm{mgl}^{-}\right.$ ${ }^{1}$ ) from site 2 during winter.

High chloride value in fresh water environment are mainly due to pollution of human and animal waste (Trivedy \& Goel, 1984) and low chloride value reflects the minimal amount of organic waste of animal origin and practically no discharge of municipal \& industrial wastes in the water. Chloride value in summer was higher in water due to increase in water evaporation leading to increase in concentration of chloride (Gupta et al, 1996).

\subsection{Magnesium:-}

It is considered as a nontoxic to human at the concentration expected in water. Concentration greater than $125 \mathrm{mgl}^{-1}$ can have a diuretic effect and magnesium concentration may vary from zero to several hundred $\mathrm{mgl}^{-1}$ depending on the source and treatment of their water. In the study Mg concentration was low. The lowest value was recorded from site $1\left(0.82 \mathrm{mgl}^{-1}\right)$ during the month of October and highest in the site $3\left(3.24 \mathrm{mgl}^{-1}\right)$ during the month of June. Magnesium carbonate and hydroxide precipitate significant on at a very high $\mathrm{p}^{\mathrm{H}}$ value (above 10) under most natural conditions (Wetzel, 1975). The high concentration of magnesium during summer in low water body was also due to concentration of nutrients in this period (Daborn, 1976). Presence of higher amount of magnesium is toxic to some aquatic organisms.

Magnesium is essential for chlorophyll bearing organism, since it goes into composition of pigments. Decreased value of magnesium may be due to plankton and algal uptake (Rath P. et al, 2000). 


\subsection{Potassium:-}

Most potassium minerals are soluble and never found free in nature. It is natural occurred element however concentration remained quite lower compare to magnesium. It is fourth naturally occurring cation in fresh water ecosystem found in the lesser concentration than sodium, calcium and magnesium and yet has a vital regulatory influence as a micro-nutrient in metabolic pathways in aquatic ecosystem. Major source of potassium in natural fresh water is weathering of rocks but the quantities increase in the polluted water due to disposal of waste water ( R.K.Trivedy and P.K. Goel, 1986).

In the study maximum valu $\left(4.36 \mathrm{mgl}^{-1}\right)$ was recorded in the month of August from site 4 and minimum value $\left(1.11 \mathrm{mgl}^{-1}\right)$ was in the month of October from site 3 . Generally, Potassium content in the lake was low, it may be due to utilization of potassium by abundant macrophytes.

Maximum concentration might be due to decomposition of plants materials from the surrounding catchment area of the lake which help in increasing in the concentration and might be due to the high influx of flood water during the rainy season.

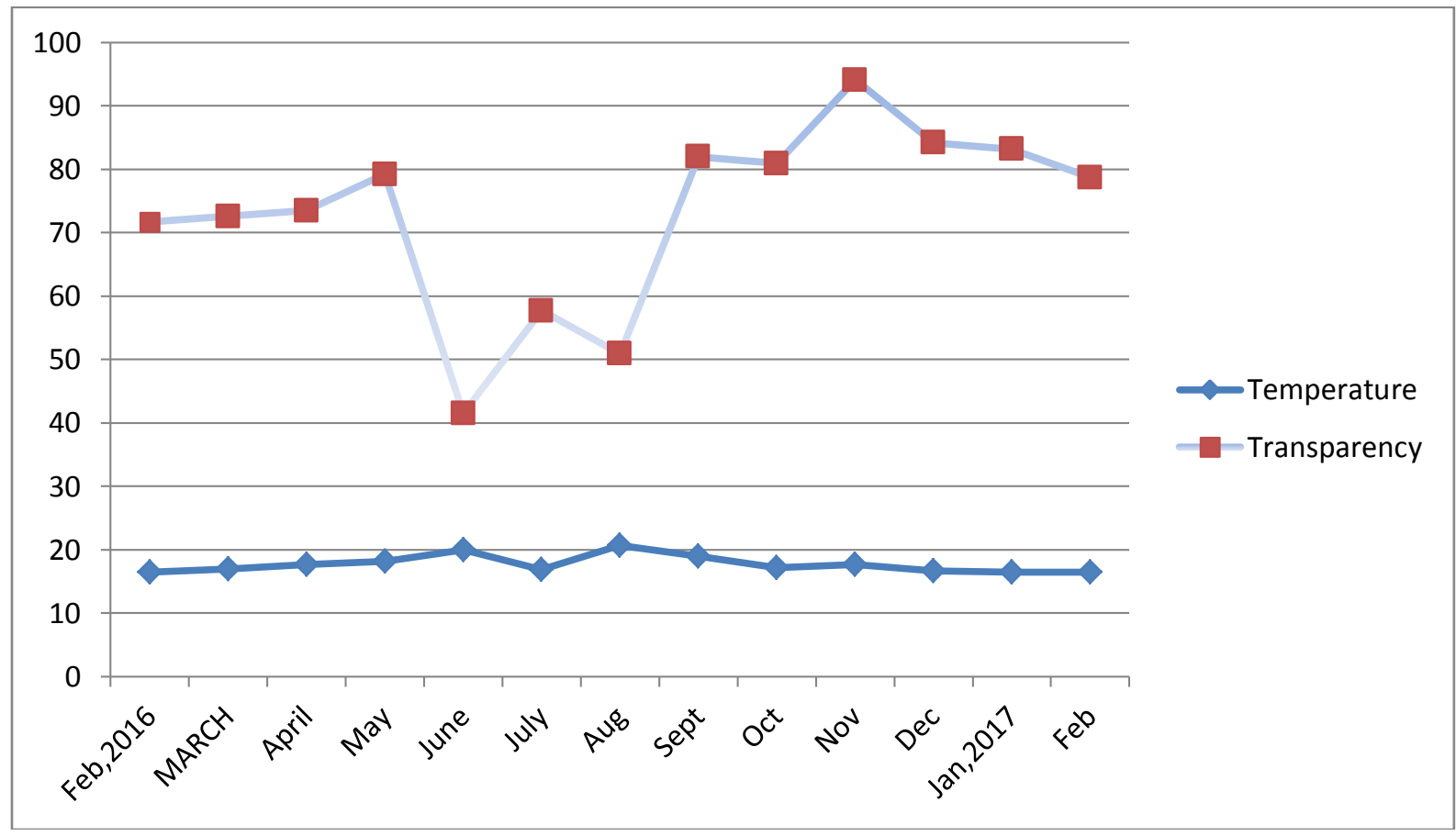

Fig. 2:- Temperature \& Transparency of water of Manungpat Thanga Island. 


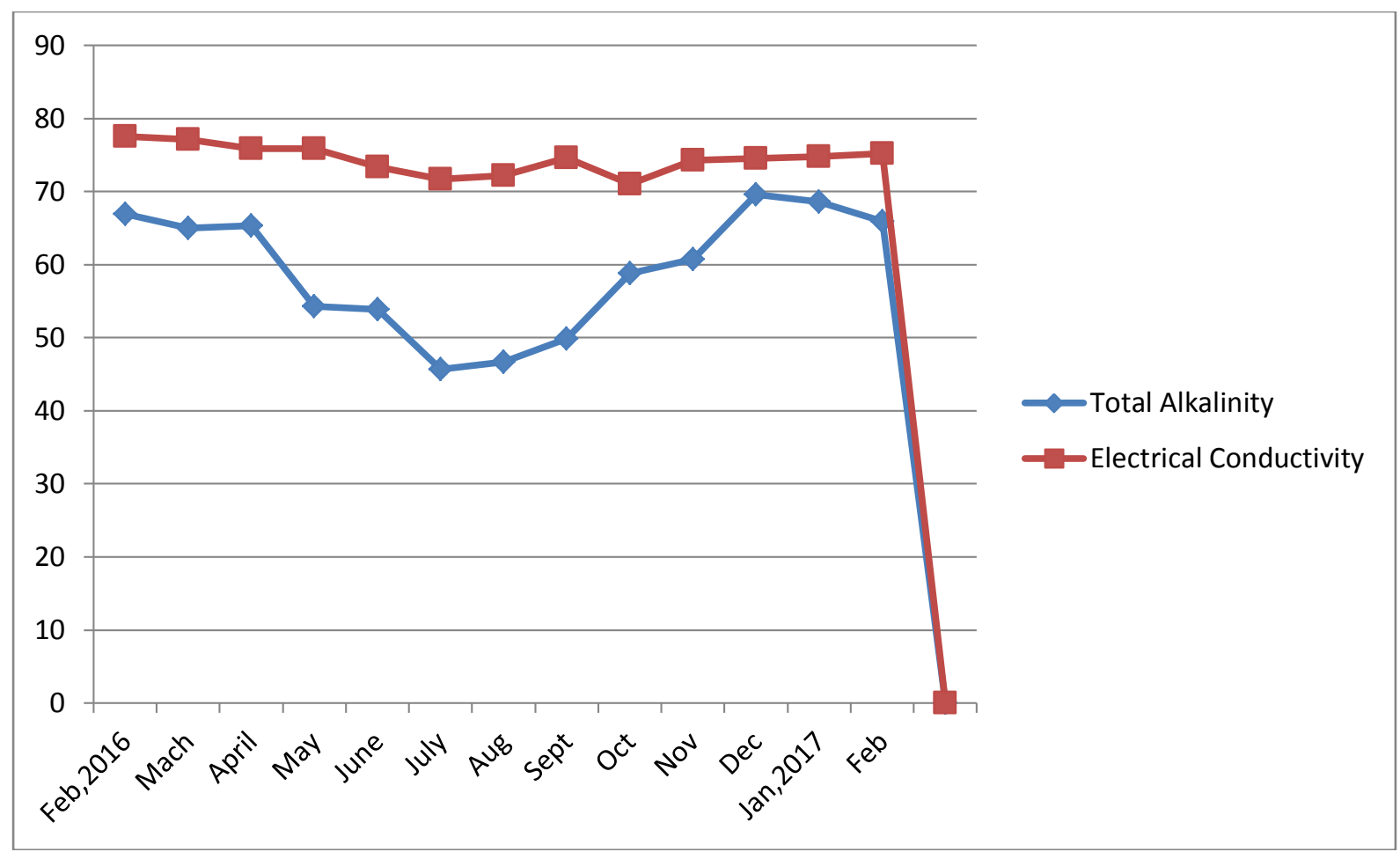

Fig.3:- Electrical Conductivity \& Total Alkalinity of water of Manungpat Thanga Island.

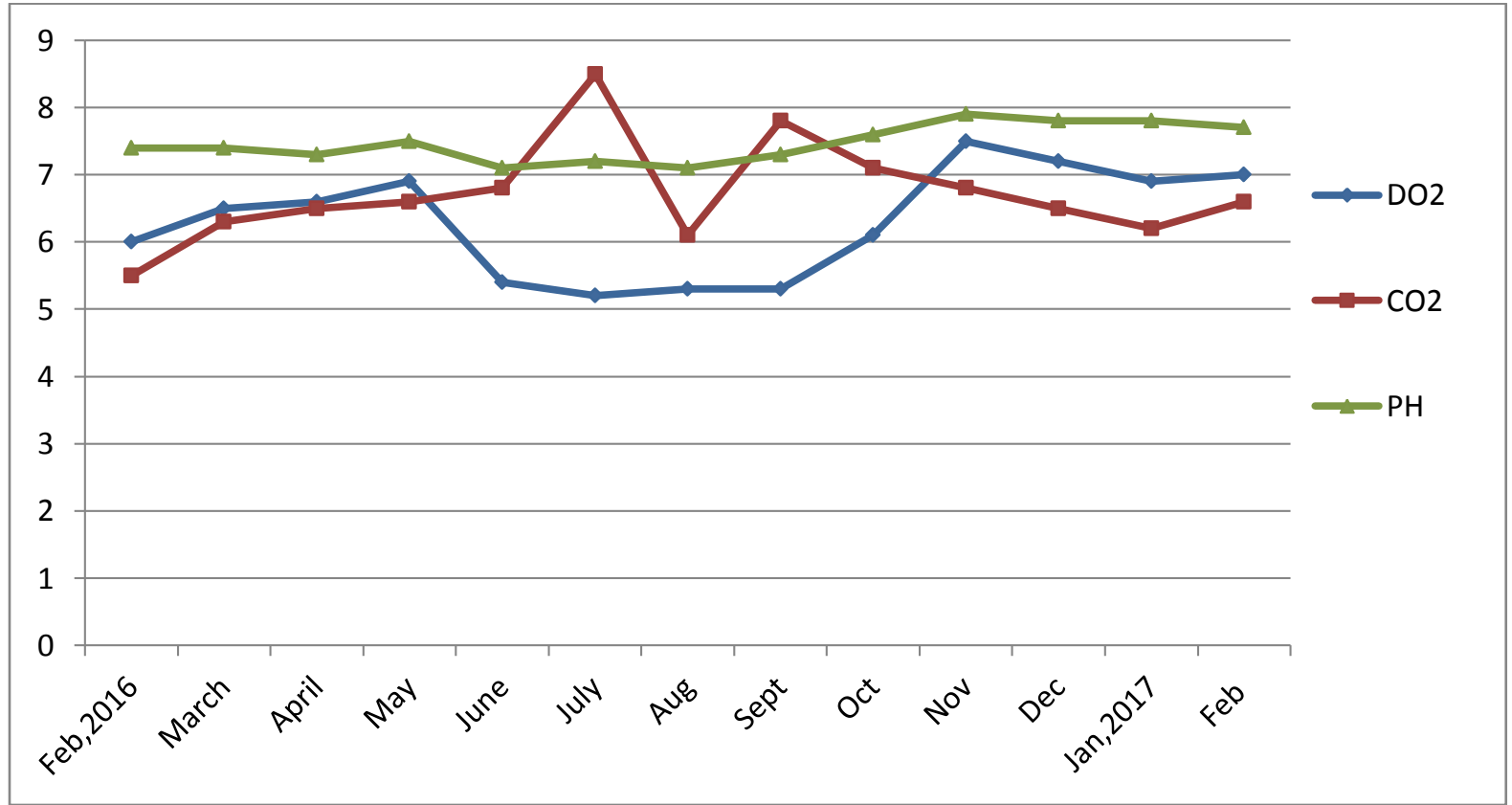

Fig.4. $\mathrm{p}^{\mathrm{H}}$ and Free $\mathrm{CO}_{2}$ and Dissolved $\mathrm{O}_{2}$ content of water of Manungpat Thanga Island. 


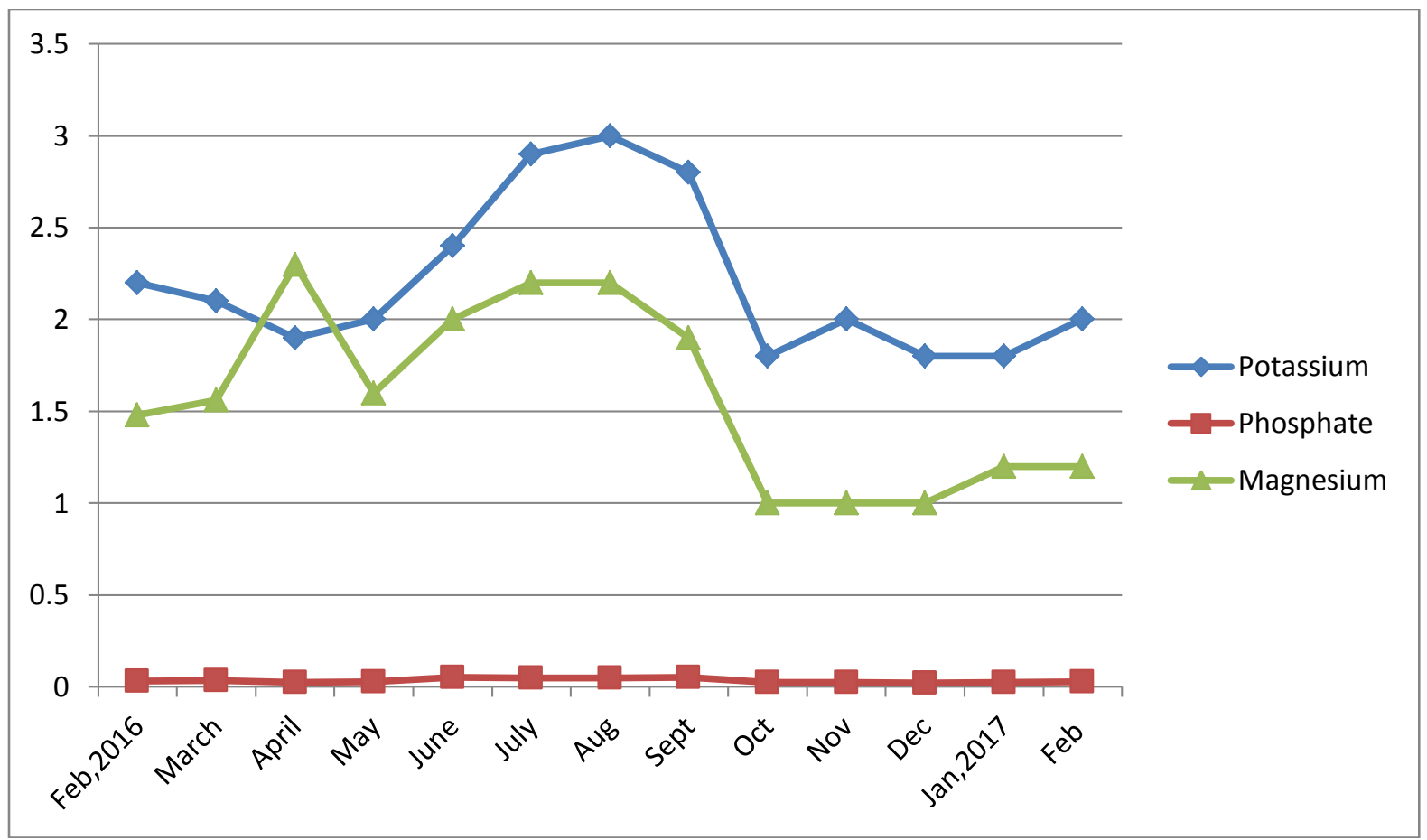

Fig.5. Potassium, Phosphate and Magnesium content of water of Manungpat Thanga Island.

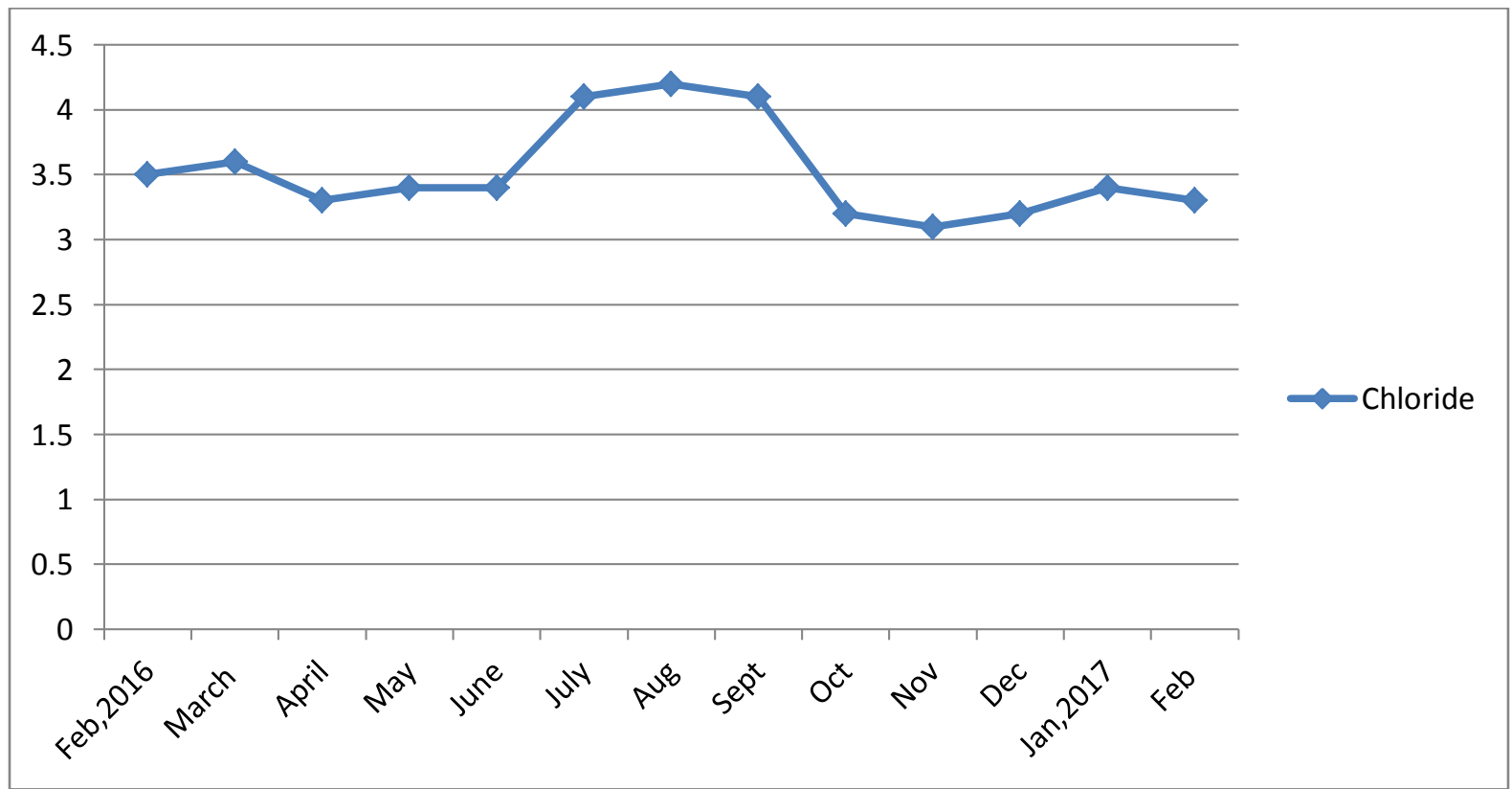

Fig.6. Chloride content of water of Manungpat Thanga Island.

\subsection{Phosphate:-}

The increased phosphate was mainly by flood, washing and mixing of fertilizers from nearby agricultural land and it was also reported by Sharman and Sarong (2004).Phosphate is a major nutrient regarding the growth and production of phytoplankton and its concentration can be used to predict the total biomass of phytoplankton (Jacob et al, 2008). In the study, the minimum value $\left(0.011 \mathrm{mgl}^{-1}\right)$ was recorded from site 3 and maximum value $\left(0.074 \mathrm{mgl}^{-1}\right)$ was from site 4. Increased phosphate concentration also produced eutrophication and bloom formation (khan and Siddiqui, 1974). Moyle (1946) opined that optimum concentration of phosphorus for sustainable and a moderate production was found to be between ( 0.1 to $0.2 \mathrm{ppm}$.) 


\section{Conclusion:-}

In the study, the parameters of Manungpat of Thanga island were not much favourable to the aquatic life specially fish survival and culture It may leads to low productivity and ultimately, reflects on socio economy of the area. Even though certain measures have been taken up by the L.D.A. (Loktak development authority) under the initiative of government of Manipur, water quality was not improved in this pat (Lake). As a whole, the lake was under the issue of rapid water quality deterioration and rapid swallowing due to unchecked biomass. This investigation would help to contribute a substantial data that can be utilized for future planning and strategy for the conservation of lake.

\section{Acknowledgement:-}

The authors are thankful to University Grants Commission, NERO, Guwahati for providing Financial Assistance to do the present minor research work. Thanks are also due to the Principal Jiri College for giving facility in the college to complete the investigation. Gratitude is acknowledged to Dr. K. Rajmani Singh associate professor, Dept. Zoology D.M. College of Science, Imphal for valuable suggestion.

\section{References:-}

1. Chakhrabarti, P.K., Roy, R.D.P singh. S. B. (1959): A qualitative study of the plankton and the physicochemical conditions of the river Yamuna at Allahabad in 1954-1955. Indian J.Fish.6(1):186-203.

2. Daborn, G.R., 1976: Physical \& chemical factors of a vernal temporan pond in western Canada. Hydrobiologia 51(1):33-38.

3. Gupta, R.K. Sharma, M., Gorai, A.C. and Pandey, P.N. (1996): Impact of coal mining effluentson the physic chemical characteristics of Raja Tank.Jaria(Dhanbad). J.Fresh water Biol.8(2):63-73

4. Jisha, Jacob, J., Nandini, N.J. and Natarajan, P. (2008): Seasonal variation of hydrographic parameters and distribution of nutrients in the veli- Akkulam lake comples. India Hydrobiology; 11(2):281-288.

5. Khan, A.A. and Siddique, A.Q., (1974): Seasonal changes in the limnology of a perennial fish pond at Aligarh, Indian Hydrobiology; 3(21):463-478.

6. Khan, M.A.G. and Chowdhury, S.H. (1994): Physical \& chemical Limnology of lake Kaptai, Bangladesh, Trop.Ecol.35(1):35-51.

7. Mansorri , H.A., Lavania, R.K. \& Tiwari, R. K.(1995): Hydrobiological study of Lakshmital lake Jhansi with special reference to plankton productivity. Flora and fauna 1(1):39-42.

8. Mathew, P.M. (1978): Limnological investigation on the plankton of Govindgrah lake and its correlation with physico-chemical factors. P.46-55,IN:Proc.Sem,Ecol. Fisheries Fresh water Reserviors (Saigal,B.N.Ed.).CIFRI. Barrakpore, November, 27-29, 1969

9. Moyle, J.B. (1946): Some chemical factors influencing the distribution of aquatic plants in Minnesota Amer Midi. Nah:34:402-426.

10. Nath, D. 2001: Water and soil characteristics of the Narmada estuary before commissioning of sadar Sarobar Dam. J. Inland fish. Soc. India, 33(2):37-41.

11. Nath, D. and De, D.K. 1999: Water and soil characteristics of different estuaries in Sundarbans.pp 126-133. In Guha, Bakshi, D.N., Sanayal, P and Nakar, K.R., Naya Prakash(Eds.), Proc. William Roxburgh Memorial Seminar on Sunderbans Mangals. Culcutta Wildlife society.

12. Nath, D. Mandal, L.N., Tripathi, S.D and Karmaker, H.C. 1994: Correlation between fish production and physico chemical parameters of water \& soil in semi intensive carp culture ponds of West Bengal. India. J.Inland fish.soc. Indian, 26(1):106-115

13. Pishak, S.M. (1996): Ecology of Loktak lake with special reference to fish and fisheries of lake. Ph.D. Thesis, Manipur University.

14. Prasad, R.R. (1956): Further studies on plankton in shore water of Mandapam. Ind.J.fish 3(1):1-42

15. Rath, P., Bhatta, D., Sahoo, B.N. and Panda, U.C., (2000): Multivariate Statistical approach to study physicochemical characteristics in Nandera Brahmani River, Angul- Talcher Belt, Orissa, India, Poll. Res., 19(4), 701710

16. Sarwar, S.K. \& Irfan-UI-Masjid, (1997) : A biotic features and diatom population of wular lake, Kashmir. Ecol. Env. \& Ens.3(5). 121-12

17. Sharma LL and Sarongs (2004): Physico- Chemical Limnolosy and Productivity of Jaosamand lake,Udaipur (rajasthan). Pollution Research; 23(1); 87-92.

18. Singh, S.P (1981): Physico chemical characteristics and macrophytes of Naukuchiya Tal: A mid altitude lake of Kumaun, Himalaya (India). Trop. Ecol. 22(1):40-53. 
19. Trivedy, R.K. \& Goel, P.K. (1984): Chemical and Biological methods for water pollution studies. Environmental publication, Karad, 215pp.

20. Wetzel, R.G., 1975: Limnology, W.B. Saunders Co., Philadelphia, 743P.

21. Wright, R., (1982): Seasonal variation in water quality of a West Africa river (R Jong in Seirra Leone). Revue d Hydrobiologie Tropicale.15(3):193-199.

22. Yusuf, A.R., Balkhi,M.H. and Qadri, M.Y. (1986) : Limnological features of a forest lake of Kashmir. J.Zoo.Soc. India 38(1\&): 29-42.

23. Zutshi, D.P., Subia,B.A., Khan, M.A. and Vanganeo,A, (1980): Comperative limnology of nine lakes of Jammu \& Kashmir, Himalayas. Hydrobiologia 72:101-102. 